\title{
A RETROSPECTIVE ANALYSIS OF THE PALLIATIVE SURGICAL TREATMENT IN PATIENTS WITH MALIGNANT PLEURAL EFFUSION
}

\author{
Krajnakova G ${ }^{1}$, Dzian $A^{2}$, Skalicanova $\mathbf{M}^{2}$, Hamada $L^{2}$, Malik $\mathbf{M}^{2}$, Grendar $\mathbf{M}^{3}$ \\ ${ }^{1}$ Jessenius Faculty of Medicine in Martin, Comenius University in Bratislava \\ ${ }^{2}$ Clinic of Thoracic Surgery, the Jessenius Faculty of Medicine in Martin, \\ Comenius University in Bratislava, and Martin University Hospital \\ ${ }^{3}$ Biomedical Center Martin, Jessenius Faculty of Medicine in Martin, \\ Comenius University in Bratislava
}

\begin{abstract}
A b s t r a c t
Introduction: The formation of malignant pleural effusion (MPE) is a clinical manifestation of an advanced malignancy or its dissemination. The focus of treatment is primarily palliative and aimed at relieving symptoms, especially dyspnoea.

Material and Methods: Clinical data from patients who were hospitalized at the Clinic of Thoracic Surgery, JFMED CU and Martin University Hospital, in the years 2015-2019 were retrospectively explored and statistically analyzed based on their medical records.

Results: From the group of patients with proven MPE (n=67), 32 patients were male (48\%) and 35 were female (52\%). The mean age was 62.3 years (65.4 for males and 59.4 for females). The three most common primary malignancies were lung cancer $(n=24)$, breast cancer $(n=14)$, and kidney cancer $(n=6)$. In 38 patients with MPE a talc pleurodesis via VATS was performed, with a median survival of 341 days (95\% CI 256-859). Drainage following the talc slurry pleurodesis was performed in 10 patients with a median survival of 91.5 days (95\% CI 64-NA). Ten patients with MPE underwent drainage only. The overall median survival time after all types of surgical interventions was 301 days (95\% CI 207-389 days).

Conclusion: Management of MPE depends on the patient's prognosis. A definitive intervention is required in patients with a long-term survival, while in patients with a short life expectancy procedures leading to the shortest hospital stay are preferred. Videothoracoscopic procedures with pleurodesis represent an effective treatment for patients with symptomatic MPE with a good performance status, presence of lung re-expansion following pleural drainage or expected survival.
\end{abstract}

Key words: malignant pleural effusion, videothoracoscopy, pleurodesis, survival

\section{INTRODUCTION}

Malignant pleural effusion (MPE) affects a number of patients worldwide and is associated with high morbidity and mortality. It is estimated that it affects more than 100,000 people in Europe [1]. Some authors report that the incidence of pleural cancer with MPE in Europe is estimated to approximately 375,000 to 400,000 patients per year [2]. The survival of patients with MPE is estimated to 3 to 12 months [3]. Although there are no studies documenting the rate of hospitalization of all patients, clinical experience suggests that majority of patients seek medical care primarily for the management of MPE-related symptoms [1].

The most common presenting symptom is breathlessness [3]. As the effusion increases, lung tissue is compressed and atelectasis occurs. Other manifestations include cough,

Corresponding author: Assoc. Prof. Anton Dzian, M.D., PhD.; e-mail: anton.dzian@jfmed.uniba.sk (C) 2021 Dzian A. et al.

This work is licensed under the Creative Commons Attribution-NonCommercial-NoDerivs 4.0 License (https://creativecommons.org/licenses/by-nc-nd/4.0/) 
fever, pleuritic chest pain, night sweats, and cachexia [4]. The risk of inflammatory complications is significantly higher due to a previous chemotherapy or radiotherapy for a malignant disease [5]. MPEs develop most commonly in patients with lung cancer, followed by breast cancer and lymphoma [2, 6-8]. Less commonly associated malignancies include malignant mesothelioma, gynaecological and gastrointestinal tumours [9]. Approximately 7-11\% also occur with unknown primary malignancy [1].

MPEs are confirmed by a detection of malignant population of cells in pleural fluid or in pleural tissue obtained by needle biopsy, thoracoscopy, thoracotomy, or autopsy [6]. Cytological analysis of MPE can provide useful diagnostic information, especially using immunohistochemical methods for differentiating tumour types. However, biopsy remains the gold standard [10, 11]. In many patients with cancer, neoplastic cells cannot be detected in pleural fluid or pleural tissue although the effusion may be caused by cancer. These effusions can be categorized as „paramalignant”, in which there is no direct pleural involvement with the tumor and no other cause of the effusion has been identified [12-14]. This can be caused by an obstruction of mediastinal lymph nodes, bronchial obstruction, superior vena cava syndrome [15], or pulmonary embolism [6, 16]. The effusions may be the result of systemic manifestations of cancer or may appear as a result of the therapy, which should be considered [13, 17].

The options of pleural interventions for MPE include thoracentesis, chest tube drainage, insertion of indwelling pleural catheter (IPC), talc pleurodesis via medical thoracoscopy, video-assisted thoracoscopic surgery (VATS) or chest tube (slurry), and thoracotomy [11]. Other methods such as pleurectomy or pleuroperitoneal shunt are rarely used in clinical practice $[6,9,16,18]$. Persisting or recurrent pleural effusions are usually managed by pleurodesis to improve dyspnoea [19]. This can be performed by VATS with talc poudrage insufflation or by injection of talc slurry into the chest tube [11]. Studies recommend the placement of a tunneled indwelling pleural catheter (IPC) in patients who cannot undergo pleurodesis or have non-expandable lung [19, 20], but in Slovakia IPCs are not yet commonly used. The inserted chest drain can be connected to Heimlich valve, that could be realized if pleural effusion persists and its daily production is high [16]. There have been significant advancements in the management of patients with MPE in the last years, as reflected by the new ERS/EACTS [11] and ATS/STS/STR guidelines [20].

The aim of the presented study is to analyze the clinical data of patients hospitalized at the Clinic of Thoracic Surgery and to evaluate the survival of patients with malignant pleural effusion.

\section{MATERIAL AND METHODS}

Patients with fluidothorax, hospitalized at the Clinic of Thoracic Surgery, the Jessenius Faculty of Medicine in Martin, Comenius University in Bratislava, and Martin University Hospital from January 2015 to December 2019 were included in the retrospective study. The source of information was a record from their medical documentation. We determined the following parameters of the monitored group: patient's gender and age, site of primary malignancy, location and character of the effusion. We evaluated procedures performed and median survival times. We also included those patients who were alive at the time of the study.

Talc pleurodesis, as the most common palliative procedure in patients with MPE, is performed at our clinic in two ways - by administering a solution of talc through the chest drain or intrapleural administration of talc poudrage during VATS. When administering talc through the chest drain, the patient must initially undergo a thoracic drainage with evacuation of pleural effusion. When the daily production into the chest drain is below $150 \mathrm{ml}$, we carry out a controlled chest X-ray and a subsequent talc pleurodesis. We administer talc via a drain using $4 \mathrm{~g}$ of sterile talc diluted in $50 \mathrm{ml}$ of physiological saline. The chest drain 
is clamped for 4 hours and the patient is positioned for at least every half an hour. If the production into the drain is less than $150 \mathrm{ml}$ by the next day, we remove the chest drain. During the administration of talc we give the patient analgesics. There may be transient dyspnoea, pain, fever, or other flu-like symptoms. The second option of talc pleurodesis is its administration through videothoracosopy. In most cases, videothoracoscopy is performed through 2 ports. After evacuation of fluidothorax, possibly, disruption of adhesions or pleural biopsy, we insufflate the talc poudrage from an original sterile bottle. The advantage of this method is the evacuation of fluidothorax with talc plurodesis in one step, the disadvantage is the need for general anesthesia.

The data were explored and analyzed using $\mathrm{R}$ Core Team ver. 4.0.2, with the aid of libraries gtsummary, survival, and survminer. The null hypothesis of no difference between two surgical curves was tested by a log-rank test. P-value below 0.05 was used to imply statistical significance. We used the non-parametric Kaplan-Meier method for the survival analysis. The obtained data were correlated with data in published foreign studies. The retrospective study was approved by the Ethics Committee of JFMED CU (protocol No. $75 / 2019)$.

\section{RESULTS}

The retrospective study included 207 patients who were hospitalized for present fluidothorax. There were created 6 groups. The largest group consisted of malignant pleural effusions (32\%), followed by paramalignant effusions $(27 \%)$ and exudates associated with inflammation (17\%). A separate group consisted of „other and not otherwise specified effusions“ (14\%; transudates in congestive heart failure, hepar cirrhosis, abscesses, effusions in rheumatoid arthritis, abnormal cytological findings without manifestation of acute inflammation or malignancy). Another group consisted of effusions of non-tumor etiology of hemorrhagic character (6\%; most often post-traumatic) and effusions of empyema character (5\%).

The group of malignant effusions consisted of effusions in which a primary or secondary pleural tumor was detected by a pleural biopsy or cytology. The diagnosis of pleural carcinosis was supported by a positive videothoracoscopic finding. There were included 67 patients (32 male and 35 female) with an average age of 62.3 years (65.4 for men and 59.4 for women). Thirty-five effusions were right sided $(52,2 \%), 27$ were located in the left hemithorax $(40,3 \%)$, and 5 were bilateral $(7,5 \%)$. The most frequently diagnosed primary malignancy was lung cancer in 25 patients (37\%), followed by breast cancer in 14 patients (21\%), kidney cancer in 6 patients (9\%), and malignant mesothelioma in 5 patients $(7,5 \%)$. In 5 patients $(7.5 \%)$ no primary tumour was identified. Other causes and characteristics of the group are shown in Tab. 1.

The number of patients with paramalignant pleural effusion was 55 (33 men and 22 women). The mean age was 66.2 years (66.6 for men and 65.5 years for women). Lung cancer occurred in 14 patients (25\%), breast cancer in 10 patients (18\%). Tumors of the gastrointestinal tract accounted for 13\% (7 patients), pancreatic cancer for $11 \%$ (6 patients), renal cancer for 9,1\% (5 patients), gynecological cancer for 5,5\% (3 patients), and lymphoma for $7,3 \%$ (4 patients). Other concomitant malignancies (prostate cancer, gastrointestinal cancer, liver cancer, myeloma, bladder cancer, unknown origin) were present in one case of each type of these malignancies.

In our study the performed procedures in patients with MPE were evaluated (Fig. 1). VATS procedures were performed in 48 cases $(72 \%)$, of which 38 cases with macroscopically pleural carcinosis were supplemented by a talc pleurodesis (57\%). In 10 patients (15\%) VATS and drainage without talc supplementation was performed. Drainage and subsequent talc pleurodesis (talc slurry) were performed in 10 patients $(15 \%)$ and drainage only in 6 patients (9\%). Due to a high daily production into the drain, 16 patients were discharged with the chest tube left on the Heimlich valve and pleurodesis was performed later. Because 
Table 1. Primary malignancy, sex, mean age, and median survival in patients with MPE

\begin{tabular}{|c|c|c|c|c|c|}
\hline Malignancy type & $\begin{array}{c}\text { Total } \\
(n=67)\end{array}$ & $\begin{array}{c}\text { Male } \\
(n=32)\end{array}$ & $\begin{array}{l}\text { Female } \\
(n=35)\end{array}$ & $\begin{array}{l}\text { Median survival } \\
\text { (days) }\end{array}$ & $\begin{array}{l}\text { Mean age } \\
\text { (years) }\end{array}$ \\
\hline Lung & 25 (37\%) & 12 & 13 & 341 & 65 \\
\hline Breast & $14(21 \%)$ & - & 14 & 301 & 59 \\
\hline Renal & $6(9 \%)$ & 6 & - & 131 & 62 \\
\hline Mesothelioma & $5(7.5 \%)$ & 3 & 2 & 458 & 66 \\
\hline Gynecological & $3(4.5 \%)$ & - & 3 & 26 & 61 \\
\hline Gastrointestinal & $2(3 \%)$ & 1 & 1 & 328 & 54 \\
\hline Liver & $1(1.5 \%)$ & - & 1 & 151 & 46 \\
\hline Prostate & $1(1.5 \%)$ & 1 & - & 226 & 79 \\
\hline Thyroid & $1(1.5 \%)$ & 1 & - & 219 & 69 \\
\hline Salivary gland & $1(1.5 \%)$ & 1 & - & 256 & 67 \\
\hline Melanoma & $1(1.5 \%)$ & 1 & - & 12 & 67 \\
\hline Hematologic & $1(1.5 \%)$ & 1 & - & 6 & 65 \\
\hline Prostate & $1(1.5 \%)$ & 1 & - & 192 & 78 \\
\hline Unknown origin & $5(7.5 \%)$ & 4 & 1 & 442 & 53 \\
\hline
\end{tabular}

of the primary disease and performance status of the patient, therapeutic puncture was performed once with an improvement of the condition. For the ambiguous thoracoscopy with pleural biopsy (suspected mesothelioma), there was indicated a thoracotomy with a confirmation of this diagnosis. A second thoracotomy was performed in a patient with adhesions in the pleural cavity and a tumor of unknown origin in the pulmonary hilum.

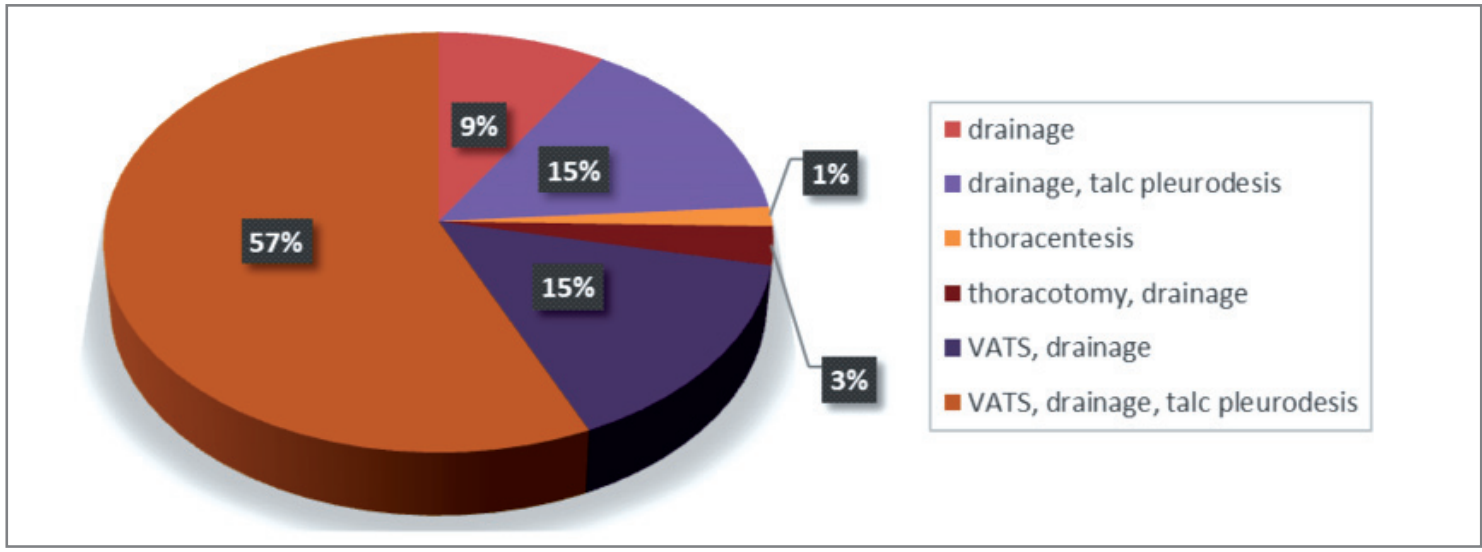

Fig 1. Performed interventions in patients with MPE during hospitalization 
We further analyzed the survival of patients with MPE from the date of the intervention. In our study an overall one-year survival from the date of the intervention was achieved by $37 \%$ of the patients with MPE ( $n=25)$. We recorded 2 deaths during the hospitalization. The median survival time in malignant pleural effusion was 301 days (95\% CI 207-389 days). The median survival time was 341 days (95\% CI 102-499) for lung cancer patients and 301 days (95\% CI 235-NA) for breast cancer patients. Patients with mesothelioma tended to have a longer survival and we recorded worse survival in gynecological-urological malignancies, malignant melanoma, and hematologic malignancy (Tab. 1). Fig. 2 represents the Kaplan-Meier survival analysis with the probability of survival in malignancy type (lung and breast cancer).

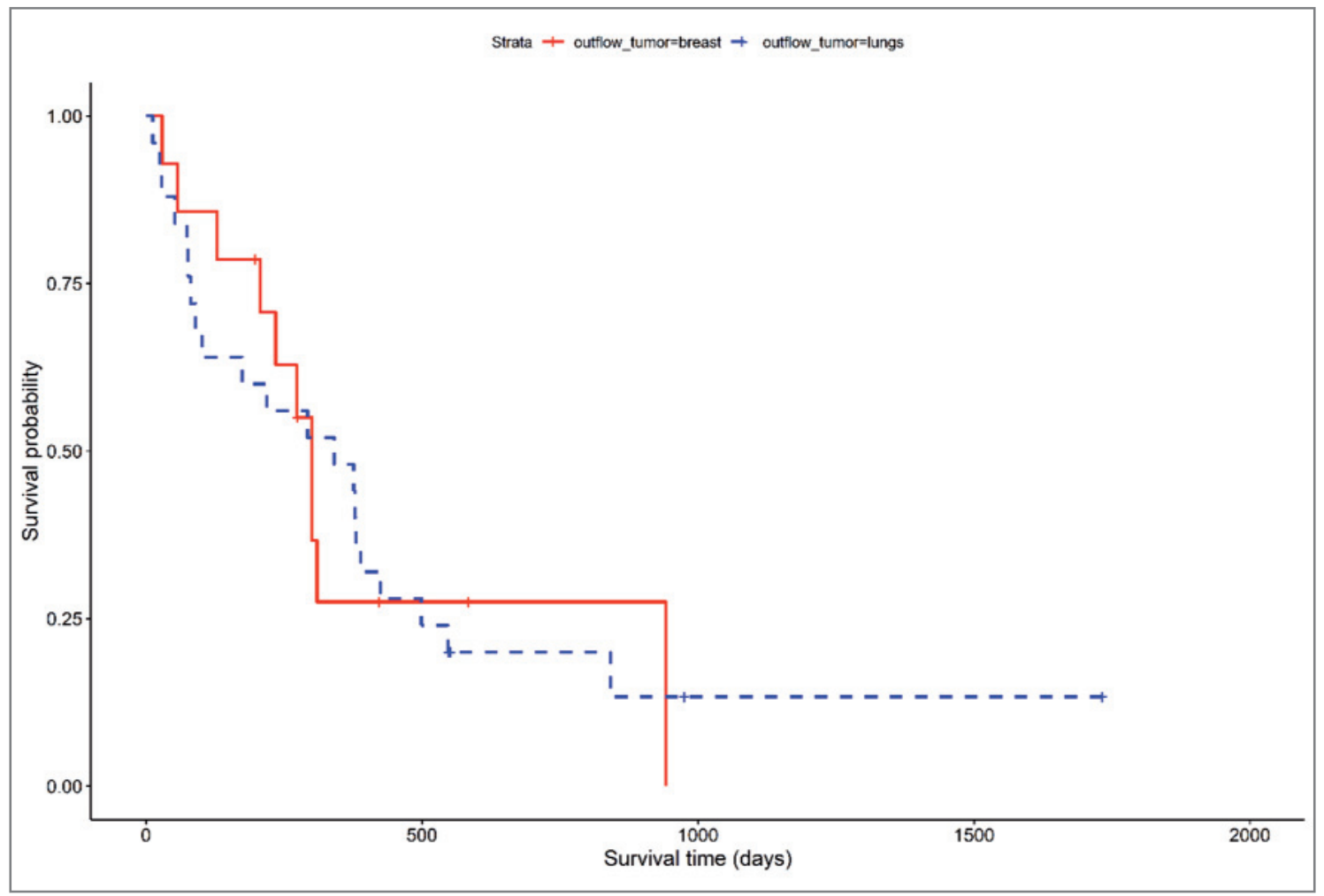

Fig. 2 Kaplan-Meier survival curves for lung and breast cancer

Talc pleurodesis via VATS was performed in 38 patients with a median survival of 341 days (95\% CI 256-859 days). Talc slurry pleurodesis was performed in 10 patients with a median survival of 91.5 days (95\% CI 64-NA). The survival times appear to be better after VATS pleurodesis, which may be related to the number of interventions performed and also to the fact that patient should have a good performance status and ability to undergo the procedure under general anesthesia. Fig. 3 shows a Kaplan-Meier curves for procedure type and compares probability of survival in two groups. 


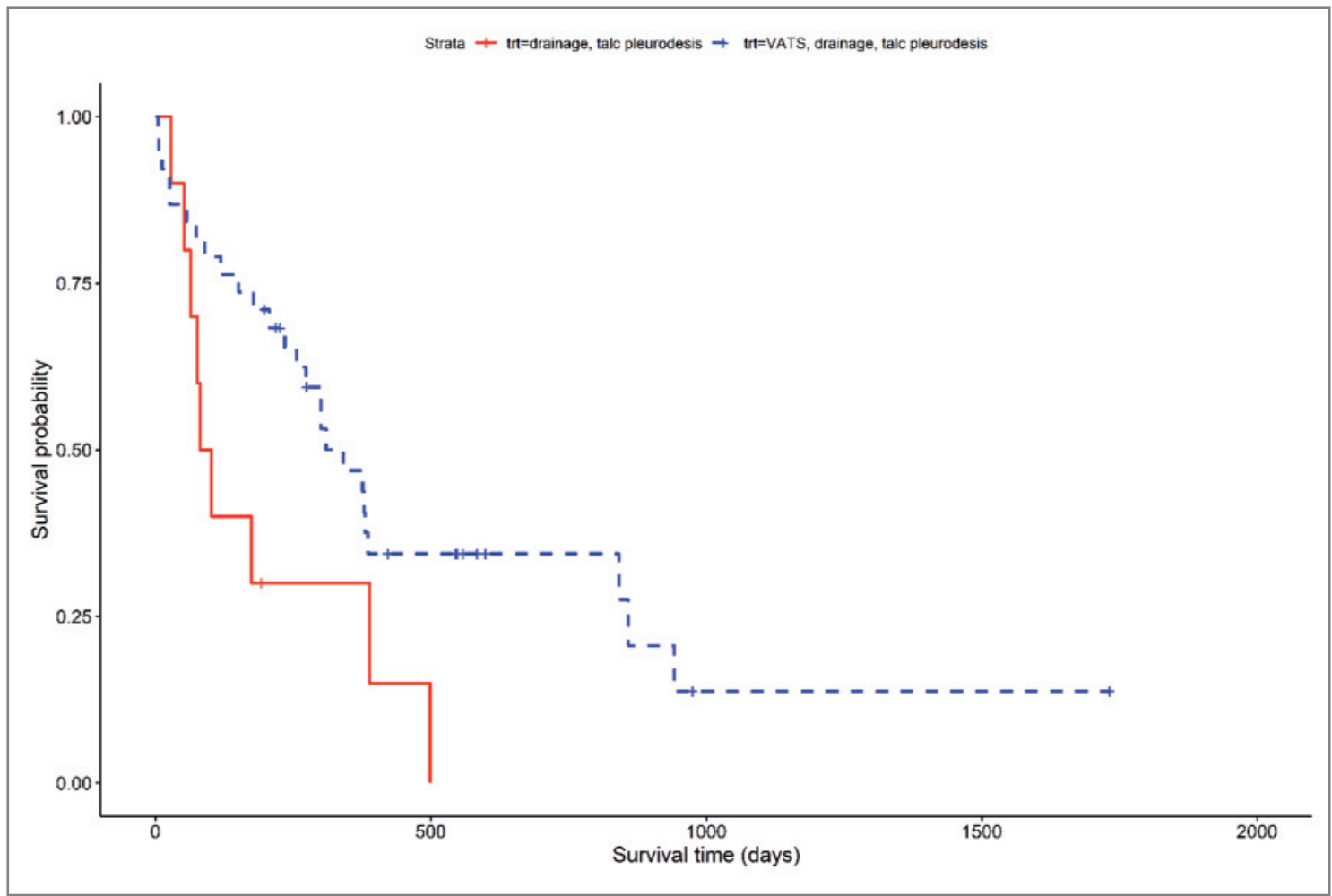

Fig. 3 Kaplan-Meier curves for intervention types

\section{DISCUSSION}

In our study MPEs were most commonly caused by a primary lung or breast cancer. Compared with data in the literature reporting malignant lymphoma as the 3rd most common malignity in patients with MPE [2,6-8], our study had a higher rate of renal carcinoma and malignant mesothelioma (Tab. 1). Paramalignant effusions represent a group in which the propagation of malignant cells in the pleural effusion or pleural histology was not demonstrated. In our group of patients, for example, these were tumors of the gastrointestinal tract and pancreas, in which fluidothorax was present.

The median survival in MPE is ranging from 3-12 months, but can vary significantly according to the performance status of the patient, cell type, staging, and whether a chemosensitive malignancy is present [19]. Some studies report a worse median survival for lung cancer than for breast cancer [9, 21]. In our study the median survival time was 301 days in breast cancer and 341 days in lung cancer patients from the day the intervention was performed (Tab. 1).

Videothoracoscopic procedures with pleurodesis and a median survival of 341 days were the most frequent treatment option of MPE in our study. Foreign studies recommend talc pleurodesis as the treatment of choice for patients with symptomatic MPE. Using long-term indwelling pleural catheters could be an alternative to talc pleurodesis (mostly in patients with trapped lungs or short life expectancy) [20, 22]. The data suggest that thoracoscopic talc poudrage (via VATS or medical thoracoscopy) may be slightly more effective than the slurry for MPE pleurodesis [23]. The treatment depends on factors such as performance status, presence of lung reexpansion following pleural drainage, or expected survival [24]. 
There are some limitations of this study, as we did not consider the comorbidities of the patient, the treatment of the primary tumour, effusion reccurence, or the prognostic factors. It is stated that the patients receiving first- or second-line systemic treatment have been reported to have a higher risk of MPE recurrence compared to the patients who underwent the treatment of MPE before the systemic treatment [25].

\section{CONCLUSION}

The results of our retrospective study show that the choice of the therapeutic approach is adapted to the expected survival of the patient. Procedures leading to the shortest hospital stay and the lowest postoperative morbidity should be reserved for patients with the shortest expected survival. Videothoracoscopic procedure with pleurodesis is the effective treatment for patients with symptomatic MPE with good performance status, presence of lung reexpansion following pleural drainage, or expected survival. The new therapeutic approaches and recommendations have grown but the management of MPE may vary from country to country. Despite advances in therapeutic options, the prognosis remains poor and mortality high. MPEs require sufficient attention and proper management, as they occur in routine clinical practice.

\section{REFERENCES}

1. Penz E, Watt KN, Hergott CA, Rahman NM, Psallidas I. Management of malignant pleural effusion: challenges and solutions. Cancer Manag Res. 2017;9:229-241.

2. Ried M, Hofmann HS. The treatment of pleural carcinosis with malignant pleural effusion. Dtsch Arztebl Int. 2013;110(18):313-318.

3. Roberts ME, Neville E, Berrisford RG, Antunes G, Ali NJ; BTS Pleural Disease Guideline Group. Management of a malignant pleural effusion: British Thoracic Society Pleural Disease Guideline 2010. Thorax. 2010;65 Suppl 2:ii32-ii40.

4. Dixit R, Agarwal KC, Gokhroo A, et al. Diagnosis and management options in malignant pleural effusions. Lung India. 2017;34(2):160-166.

5. Habal P, Omran N, Jankovičová K, Kodělková K, Krejsek J, Mand’ák J. Torakoskopicky navozená chemická pleurodéza v léčbě maligního pleurálního výpotku. Onkologie. 2014;8(1):35-8.

6. Sahn SA, Huggins JT. Malignant pleural effusions. In: Grippi MA, editors. Fishman's pulmonary diseases and disorders. 5th ed. NewYork: McGraw Hill Education;2015. p. 1164-1187.

7. Jany B, Welte T. Pleural Effusion in Adults-Etiology, Diagnosis, and Treatment. Dtsch Arztebl Int. 2019;116(21):377-386.

8. Meriggi F. Malignant Pleural Effusion: Still a Long Way to Go. Rev Recent Clin Trials. 2019;14(1):24-30.

9. Skok K, Hladnik G, Grm A, Crnjac A. Malignant Pleural Effusion and Its Current Management: A Review. Medicina (Kaunas). 2019;55(8):490.

10. Hutka Z. Karcinóm plúc z pohladu cytopatologickej diagnostiky. In: Kavcová E, Halašová E, Dzian A, editors. Karcinóm plúc. UK Bratislava, JLF Martin; 2010. p. 216-224.

11. Bibby AC, Dorn P, Psallidas I, Porcel JM, Janssen J, Froudarakis M et al. ERS/EACTS statement on the management of malignawnt pleural effusions. Eur J Cardiothorac Surg. 2019;55:116-32.

12. Sahn SA. Pleural diseases related to metastatic malignancies. Eur Respir J. 1997;10(8):1907-1913.

13. American Thoracic Society. Management of malignant pleural effusions. Am J Respir Crit Care Med. 2000;162(5):1987-2001.

14. Villanueva AG. Management of Malignant Pleural Effusions. Principles and Practice of Interventional Pulmonology. 2012;665-674.

15. Rice TW, Rodriguez RM, Barnette R, Light RW. Prevalence and characteristics of pleural effusions in superior vena cava syndrome. Respirology. 2006;11(3):299-305. 
16. Plutinský J. Karcinóm plúc a postihnutie pleury. In: Kavcová E, Halašová E, Dzian A, editors. Karcinóm plúc. UK Bratislava, JLF Martin; 2010. p. 263-293.

17. Heffner JE. Diagnosis and management of malignant pleural effusions. Respirology. 2008;13(1):5-20.

18. Ludwig C, Stoelben E. Chirurgische Therapie des malignen Pleuraergusses. Zentralblatt für Chirurgie. 2008;133(3):218-221.

19. Koegelenberg CFN, Shaw JA, Irusen EM, Lee YCG. Contemporary best practice in the management of malignant pleural effusion. Ther Adv Respir Dis. 2018;12.

20. Feller-Kopman D, David J. Management of Malignant Pleural Effusions. An Official ATS/STS/STR Clinical Practise Guideline. American Journal of Respiratory and Critical Care Medicine. 2018; 198(7):839-349.

21. Bell D, Wright G. A retrospective review of the palliative surgical management of malignant pleural effusions. BMJ Support Palliat Care. 2014;4(2):161-166.

22. Planchard D, Popat S, Kerr K, et al. Metastatic non-small cell lung cancer: ESMO Clinical Practice Guidelines for diagnosis, treatment and follow-up [published correction appears in Ann Oncol. 2019 May;30(5):863-870]. Ann Oncol. 2018;29(Suppl 4):iv192-iv237.

23. Bhatnagar R, Laskawiec-Szkonter M, Piotrowska HEG, et al. Evaluating the efficacy of thoracoscopy and talc poudrage versus pleurodesis using talc slurry (TAPPS trial): protocol of an openlabel randomised controlled trial. BMJ Open. 2014;4:e007045.

24. Clive AO, Kahan BC, Hooper CE, et al. Predicting survival in malignant pleural effusion: development and validation of the LENT prognostic score. Thorax. 2014;69(12):1098-1104.

25. Abrão FC, de Abreu IRLB, de Oliveira MC, et al. Prognostic factors of recurrence of malignant pleural effusion: what is the role of neoplasia progression? J Thorac Dis. 2020;12(3):813-822.

Received: November, 11, 2020

Accepted: December, 13, 2020 